GORAN ZOVAK, Ph.D.

IVO ČALA, Ph.D.

E-mail: icala@fsb.hr

University of Zagreb, Faculty of Mechanical Engineering

and Naval Architecture

Ivana Lučića 1, HR-10000 Zagreb, Republic of Croatia

IGOR ŠIŠKO, B.Eng.Mech.Eng.

E-mail: igor.sisko@hak.hr

Croatian Automobile Club

Avenija Dubrovnik 44, HR-10010 Zagreb,

Republic of Croatia

\title{
APPLICATION OF STANDARDS IN AUDITING OF STATIONS FOR TECHNICAL INSPECTION OF VEHICLES
}

\begin{abstract}
The HRN EN ISO/IEC 17020:2005 requirements have been applied to the auditing of the operation of the stations for technical inspection of vehicles which, as part of the system of technical inspections and registration of vehicles in the Republic of Croatia is carried out by the Croatian Automobile Club, based on the public accreditation issued by the Ministry of the Interior of the Republic of Croatia. The direct consequence of the application of this standard, i. e. the implementation of the quality management system is the improvement of the quality and efficiency in performing the respective activity, thus raising the level of technical roadworthiness of vehicles, $i$. e. traffic safety on the roads in the Republic of Croatia.
\end{abstract}

\section{KEY WORDS}

supervisory/inspection bodies, quality, quality management, technical inspection of vehicles, auditing

\section{INTRODUCTION}

The direct goal of implementing the quality management system according to HRN EN ISO/IEC 17020:2005 requirements (hereinafter - the Standard) into the auditing process of stations for technical inspection of vehicles (hereinafter - STIVs), is to improve the efficiency of the auditing itself, regarding detection and correction of irregularities in the operation of STIVs.

Road traffic safety is of national interest for the Republic of Croatia. "Vehicle", i. e. its technical roadworthiness is one of three crucial factors that directly influence road traffic safety, the other two being the "driver" and the "road". Since technical maintenance of vehicles in the exploitation conditions is of primary importance for the safety of all the traffic participants on roads, the government has stipulated the obligatory control of vehicle roadworthiness, i. e. defined the system of technical inspections and vehicle registration (hereinafter - the System) which has been defined by the provisions of the Road Traffic Safety Act (Official Gazette 67/08) (hereinafter - the Act).

Apart from the Ministry of the Interior, as the government management body authorized for the area of technical inspections and registration of vehicles, the basic organizer of the System is the technical organization defined by Article 273 of the Act, consisting of the Croatian Centre of Vehicles and the Croatian Automobile Club. The technical organization has been authorized (holder of the public accreditation) by the Ministry of the Interior to organize the System at the STIVs. The Act determines the internal auditing mechanism of the System regarding technical supervision of the work at the STIVs, which is under the authority of the Croatian Automobile Club, in compliance with the Regulations regarding auditing of stations for technical inspection of vehicles (Off. Gazette 159/04, 6/05, 32/07).

The Standard regulates the general requirements for different types of bodies that perform the inspection / supervision. The purpose of the Standard is to promote trust in those bodies that perform the inspection of compliance with its requirements. It has been developed based on the experiences of the European 
bodies performing supervision, taking into consideration the requirements and recommendations of the European and international documents such as the series of standards ISO 9000 (EN/ISO 9000) and ISO/IEC Guide 39.

The Croatian Automobile Club has brought a strategic decision on introducing the quality management system into the field of its activities that refer to the technical supervision of the operation of the stations for technical inspection. Consequently, in 2007, it has introduced into the respective activity the new operation methodology in compliance with the Standard, and since 14 May 2008 the Sector for Vehicles - Department of Technical Supervision of the operation of Stations for Technical Inspection of Vehicles of the Croatian Automobile Club has been accredited by the Croatian Accreditation Agency.

\section{THE TASK OF THE CROATIAN AUTOMOBILE CLUB WITHIN THE SYSTEM}

The basic task of the Croatian Automobile Club is the protection of the interests of the members, drivers and other road traffic participants, achievement of satisfactory level of road traffic safety with adequate environmental protection and promotion of the driving code. Also, all the tasks that result from the activities of certain public authorizations, based on the laws entrusted to the Croatian Automobile Club by the authorized government bodies, which upgrade and complement the core activity.

The task of the Croatian Automobile Club within the System is technical supervision of the proper operation of the stations for the technical inspection of vehicles, which means determining of the existing and potential factors that compromise, i. e. may compromise the proper functioning of the STIVs. Moreover, the task of the Croatian Automobile Club is reporting to the authorized government body - the Ministry of the Interior, along with the proposal of measures of procedure. The Ministry of the Interior ensures the proper functioning of STIVs by implementing the authorizations of the government administration bodies, i. e. by applying disciplinary actions and penal terms in compliance with the provisions of the Act.

Furthermore, the Croatian Automobile Club controls, i. e. harmonizes the criteria for the technical inspections and registration of vehicles in the Republic of Croatia, and acts preventively. As part of preventive actions, according to the provisions of Article 15 of the Regulations regarding auditing of stations for technical inspection of vehicles, the authorized technical auditors of the Croatian Automobile Club undertake the following activities:
- they provide assistance and technical instructions regarding the implementation of regulations and measures,

- they highlight the consequences of unskilled and negligent work,

- they initiate and organize sessions, consultations and meetings with the staff of legal entities that perform the tasks of technical inspection of vehicles regarding issues that are of interest for the professional performance of activities, undertaking also other measures and activities with the aim of professional and high-quality performance of the work.

\section{ORIGINAL ASSUMPTIONS OF THE QUALITY MANAGEMENT SYSTEM BASED ON THE STANDARD}

Considering the fact that the standard series (ISO $17000 \mathrm{ff}$ ) in the field of accreditation is also based on standard ISO 9001, i. e. ISO 9004, in accordance with the cross of the standards of the Technical Committee ISO TC 176 (responsible for the ISO 9000ff series of standards), Figure 1, it may be concluded that the original assumptions of the quality management system based on the Standard are identical to those of the ISO 9000ff series of standards.

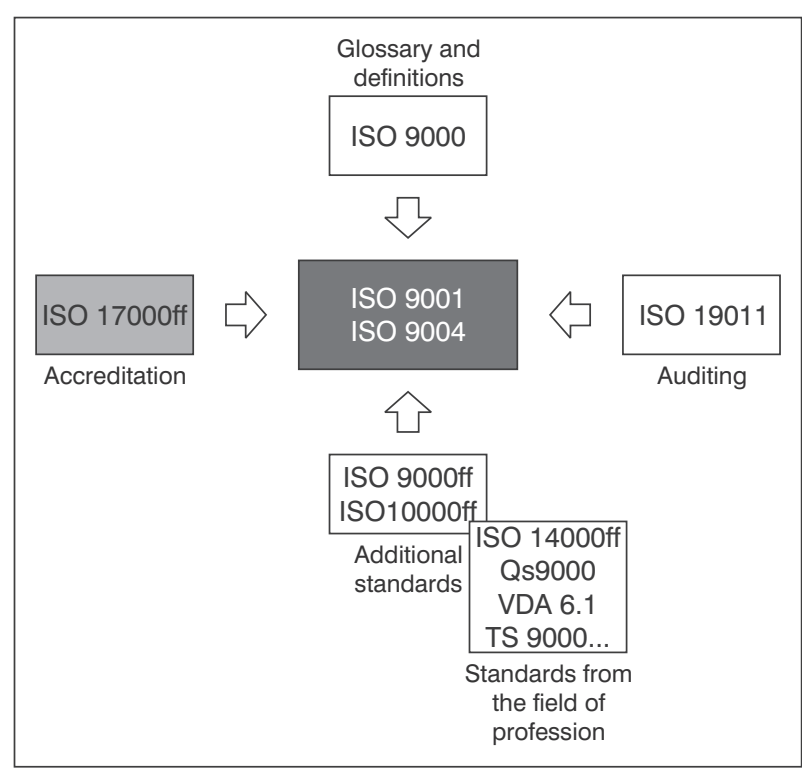

Figure 1 - Cross of standards of the Technical Committee ISO TC 176

Source: adapted from - N. Injac: "Mala enciklopedija kvalitete", Upoznajmo normu ISO 9000 I. dio, (Small Encyclopaedia of Quality, Let's meet ISO 9000 Standard” - Part 1), Oskar, Zagreb, 2002

These original assumptions include:

- the definition of policy and objectives of quality, as well as establishment of a mechanism of responsibilities for their realization, 
- the process approach, i. e. systemic determination of business processes and defining and ensuring of material and technical, and human resources for their implementation,

- defining and implementation of methods for measuring the efficiency of the business processes,

- establishing the detection mechanism, i. e. prevention of non-conformances, and elimination of their causes,

- defining and establishing of the mechanism of continuous improvement of the quality management system,

- determining of the needs and expectations of the service users.

\section{REQUIREMENTS OF THE STANDARD FOR THE INSPECTION/SUPERVISORY BODIES}

By defining the requirements for the bodies that implement inspection / supervision the preconditions have been created for the establishment of a simple, but efficient, process-oriented quality management system, within the frames of proclaimed quality policy and the planned quality objectives. In principle, the requirements of the Standard can be divided into several groups, regarding the fields of implementation:

- requirements regarding independence, impartiality and confidentiality,

- requirements regarding internal organizations,

- requirements regarding quality system,

- requirements regarding human, and material and technical resources,

- requirements regarding methods and supervision procedures (technical part).

\subsection{Requirements regarding independence, impartiality and confidentiality}

The auditing body shall be independent in the required measure regarding the conditions in which the respective activity is carried out. Regarding these conditions it shall satisfy the minimal criteria of one of three defined categories, i. e. levels of independence type $\mathrm{A}, \mathrm{B}$ or $\mathrm{C}$. The auditing body of type $\mathrm{C}$ is defined according to the Standard as the auditing body which is included in the design, production, supply, introduction, use or maintenance of supervised items (product, process, service, etc.), and which can provide auditing services to other organizations (except its host company).

The Croatian Automobile Club is in the process of being accredited for the auditing body of type $\mathrm{C}$, since it technically supervises the operation of STIVs with the core activity of performing technical inspections and registration of vehicles, while on the other hand, as technical organization together with the Vehicle Centre of Croatia they bring certain general acts - regulations that define the provisions of the System - and in this way "design", i. e. "form" the System itself.

The auditing body shall have developed mechanisms for the protection against internal and external influences that efficiently prevent such activities that may potentially lead to compromising of competencies, impartiality and integrity of their personnel. Also, the auditing body has to safeguard the confidentiality and property rights of all information and data that are obtained during the inspection / auditing.

\subsection{Requirements regarding internal organizations}

The auditing body or organization of which this body is part, has to have legal identity, i. e. if it is part of the organization which performs also other activities apart from supervision, it has to be identifiable within the organization.

One of the requirements is also appointment of a responsible person, who is qualified and with adequate experience to manage the auditing body, and who takes full responsibility for the implementation in compliance with the Standard. Also, the auditing body has to have an appointed person who will represent the responsible manager in case of their absence.

In compliance with the internal organization and systematization of workplaces of the Croatian Automobile Club, the process of technical auditing of the operation of the STIVs, in accordance with the Standard requirements, is performed within the Department for Vehicles (the Sector manager is the responsible person), within a separate organizational unit Department for Technical Auditing of the operation of the STIVs (head of the Department substitutes the Sector manager in case of their absence).

The auditing body shall have adequate liability insurance and independently controlled accountancy.

\subsection{Requirements regarding Quality system}

The quality policy definition is one of the basic requirements regarding the quality system, and it includes the determined principle of operation by implementing of which the auditing body guarantees the proclaimed level of quality. The quality policy has to be understandable and applicable at all the auditing body levels.

Furthermore, in compliance with the quality policy, the quality objectives are defined and they have to be measurable. By defining the quality objectives the methods and scheduling of their implementation are determined, as well as the organizers of activities that understand their implementation. 
The auditing body management has to appoint a person with clearly defined authorities and responsibilities to ensure the proclaimed level of quality in the auditing body. This person is in charge of maintaining and constantly upgrading the quality system, being in direct contact with the auditing body top management, and under no influence whatsoever of any pressures nor conflicts of interest that could influence their work (at the Croatian Automobile Club it is the Quality Manager).

The quality management system according to the Standard means that there is quality documentation.

The documentation structure is divided into three levels:

- the first level of documentation (strategic)

includes the Quality Manual and the Book of Procedures. The Quality Manual is the fundamental document of the quality system and it generally determines the management system, i. e. refers to adequate documentation of lower levels, which contain detailed descriptions of all the activities which fulfil the Standard requirements. The Book of Procedures is a document which defines the business processes, and is based on the Quality Manual.

- the second level of documentation (tactical) includes the quality system procedures which describe the objective, responsibility, schedule of activities (flowchart) necessary to perform the activities.

- the third level of documentation (operative)

includes work instructions that elaborate in detail the method of performing certain activities, and may be related to a certain procedure of the quality management system or may be part thereof. This level of documentation also includes the forms, i. e. all the records (internal documents) that result from the system as evidence that the activities have been carried out.

Also, the auditing body shall have an established quality documentation management mechanism (including records), which includes the ordering of the sequence of activities and authorities during development, modifications, and design, application and implementation control, as well as archiving of documentation.

Within the context of performing the policy of permanent improvement of the quality system the auditing body shall have an established mechanism of periodical internal auditing of the quality system in order to detect the established, i. e. potential non-conformities that compromise or may compromise the efficiency of complying with the Standard requirements. As part of the mentioned mechanism corrective actions have to be defined, i. e. procedures to eliminate all such non-conformities.
The auditing body also has to have a defined quality system assessment procedure by the management.

\subsection{Requirements regarding human and material-technical resources}

The auditing body shall define the necessary resources and ensure their availability in realizing the processes i. e. for efficient functioning of the quality management system.

Human resources of the auditing body shall be competent, i. e. have adequate academic qualification, education, experience and professional knowledge in the domain of activities which include auditing. Their professional knowledge, i. e. professional competences have to be at a level that guarantees that they are capable of making professional assessments on conformity with the defined requirements, i. e. detect all the deviations. The auditing body shall have defined mechanisms of education and training of the existing and new personnel, and a determined code of behaviour. Also, the auditing body shall have a regulated assessment procedure of their personnel. The incomes of the auditing body members shall not depend directly on the number of performed audits nor on their results.

The auditing body shall have available all the material and technical resources, especially instruments and equipment, which are required for the audits. The fundamental material and technical resource of the Croatian Automobile Club to perform professional audits over the operation of the STIVs is the electronic database on all the performed technical inspections and registrations of vehicles in the Republic of Croatia (all the STIVs in the Republic of Croatia are computer networked into a unique system) and an electronic database about all the performed audits over the STIVs. In compliance with the Standard requirements the procedures for the protection of the integrity and security of data have been defined.

\subsection{Requirements regarding supervision methods and procedures}

The auditing institution has to use methods and procedures determined in the requirements according to which the conformity has to be defined.

The professional auditing of the work at the STIVs has been defined and analysed in the Book of Procedures, Figure 2.

Methods and procedures of the professional auditing of STIVs have been conceived in such a way that their application guarantees efficient detection of potential and the existing irregularities in the work of STIVs, as well as ensures the conditions for their elimination in order to ensure proper functioning of the STIVs. 


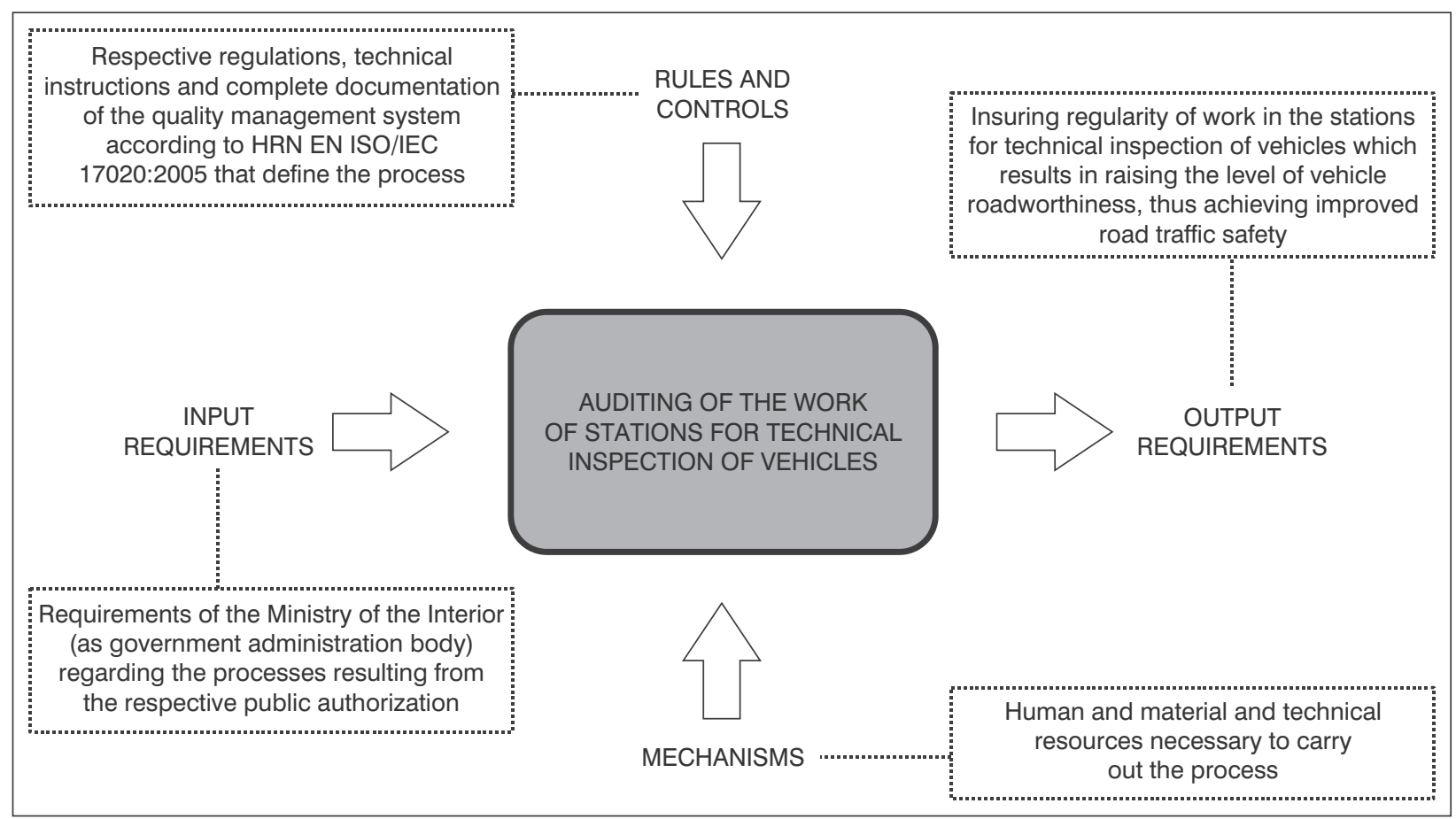

Figure 2 - Schematic presentation of professional auditing processes regarding work of STIVs

Source: Adapted from - Knjiga procesa (Book of Procedures), Code: 102.10, revision 03/01-08, (quality management documentation), Croatian Automobile Club, Zagreb, 2002

The break-up of the processes of auditing the STIVs is presented in Figure 3. The auditing of STIVs consists of six procedural steps:

1. planning of regular audits,

2. preparation of audits,

3. audits,

4. reporting on the performed audits,

5. control of the performed activities, by STIVs, determined during the audits (based on the Protocol regarding auditing of the STIVs - as necessary,

6. professional analysis of the work of the STIVs.

Each of the mentioned procedural steps has been elaborated by the respective procedures, i. e. work instructions, and forms (quality management documentation of the $2^{\text {nd }}$ and $3^{\text {rd }}$ level).

Further in the text, the third procedural step has been specially analysed, the auditing, since the application of new working methodology is operatively the one mostly represented within the procedures precisely of this procedural step, i. e. it has the highest influence on the increase in efficiency of implementing audits at STIVs.

As part of the procedural step of performing the audit, the authorized persons of the Croatian Automobile Club control all the aspects of the work at the stations for technical inspection of vehicles, i. e. the mentioned procedural step consists of the following phases, Figure 4:

1. Control of administrative and legal aspects of work
- includes control of respective solutions, contracts, licences, clearances, permits and stamps.

2. Control of facility

- includes control of all the premises, technological lines, roof, entry and exit automatic gates, and STIV environment.

3. Control of instruments

- includes control of existence (at STIV), efficiency and certification stamps of all the instruments determined by the Regulations on technical inspection of vehicles (Off. Gazette 136/04, 38/06, 119/06, 11/07).

4. Control of equipment

- includes control of existence (at STIV), efficiency of equipment required for flawless work of STIV.

5. Control of work of the vehicle roadworthiness supervisor

- includes control of direct performance of all the work operations defined by the Regulations on technical inspection of vehicles (Off. Gazette 136/04, 38/06, 119/06, 11/07) and technical instructions, as well as control of the respective documentation/records.

6. Control of work of the agents for technical inspection and registration of vehicles

- includes control of direct performance of all the activities defined by the Regulations on technical inspection of vehicles, Regulations on vehicle registration (Off. Gazette 5/05, 19/05, 


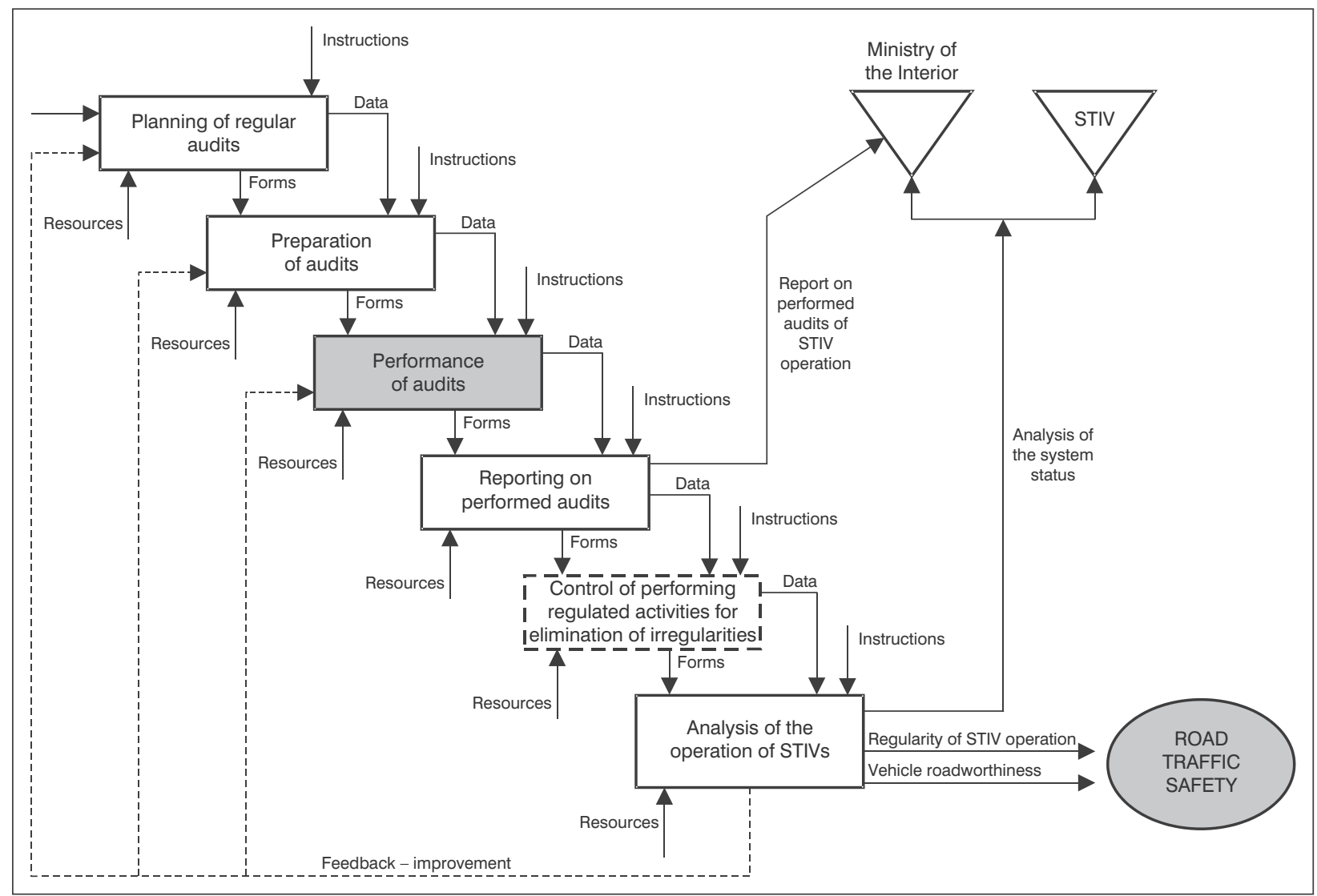

Figure 3 Schematic presentation of the break-up of auditing at STIVs

Source: Adapted from - Knjiga procesa (Book of Procedures), code: 102.10, revision 03/01-08, (quality management system documentation), Croatian Automobile Club, Zagreb, 2002

41/05, 8/06, 130/06, 13/07, 68/07) and professional instructions, as well as control of respective documentation / records.

7. Control of legal management of financial means

- includes control of dynamics and methods of managing financial means the allocation of which is legally defined (the means allocated to the national road traffic safety programme, county road administrations, fund for environmental protection and energy efficiency, etc.).

During all the phases of the mentioned procedural step the authorized persons of the Croatian Automobile Club use the so-called protocols (forms from the level 3documentation), thus excluding the possibility of "skipping" the control of individual aspects of auditing. All the findings (establishment of facts) about

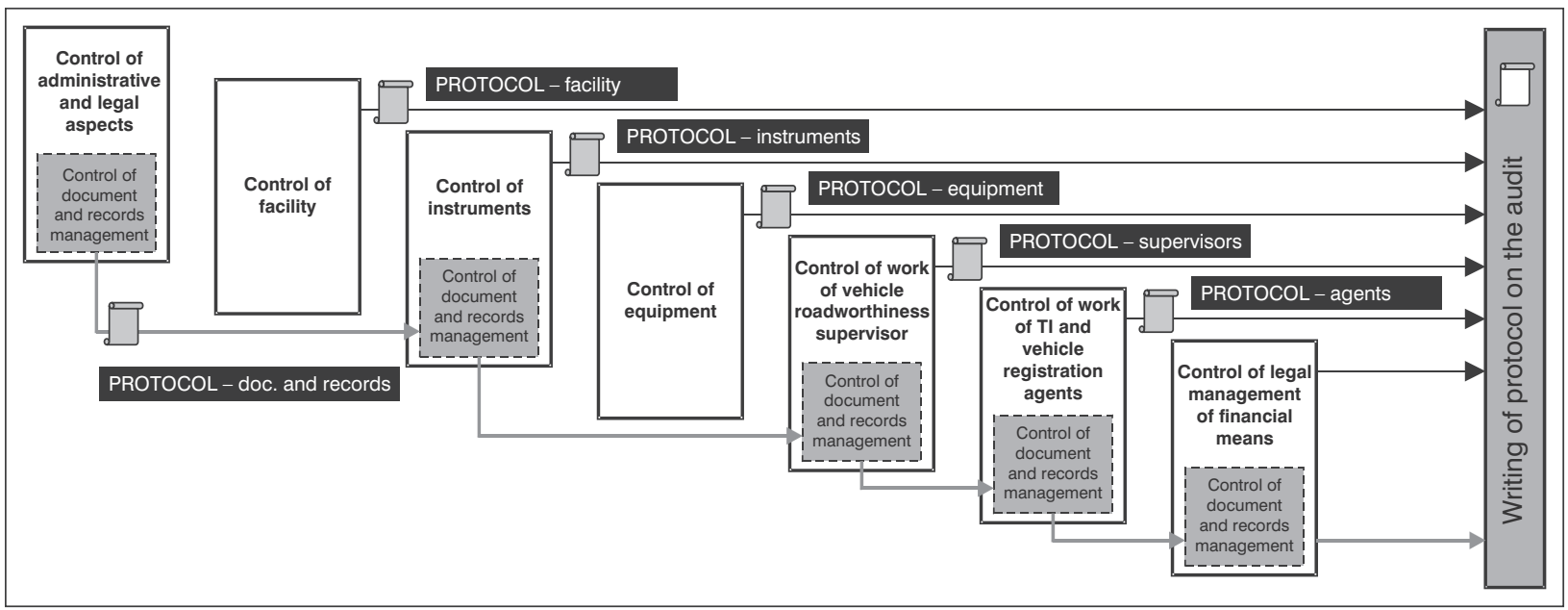

Figure 4 - Schematic presentation of procedural step of performing audits

Source: Adapted from - Quality Manual, Postupak provođenja stručnog nadzora (Procedure of auditing), Code: PO 102.10.03, revision 03/03-08, (quality management system documentation), Croatian Automobile Club, Zagreb, 2002. 
the respective auditing aspect, relevant to determine possible irregularities in the work, and to determine the measures for their elimination, i. e. writing of the protocols about the auditing of STIV.

\section{STATISTICAL INDICATORS - COMPARISON OF YEARS 2006/2007}

During 2006, i. e. during audits of the work of STIVs according to the old working methodology (which was not in compliance with the Standard requirements) the Croatian Automobile Club performed 326 audits, which determined 328 irregularities in the work of the STIVs.

In 2007, i. e. during the audits of the work of STIVs according to the new working methodology (which is in compliance with the Standard requirements) the

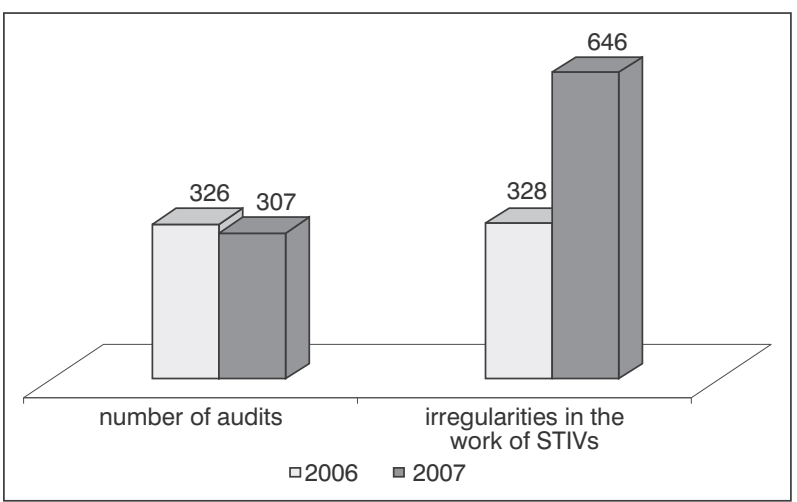

Figure 5 - Comparison of the number of performed audits and the number of identified irregularities in the work of STIVs in 2006 and 2007

Source: Electronic database of performed audits (Report), Croatian Automobile Club, Zagreb.
Croatian Automobile Club performed 307 audits which determined 646 irregularities in the work of STIVs, Figure 5, which is an increase of as much as $97 \%$ compared to 2006.

Figure 6 shows the structure of the determined irregularities in the work of STIVs according to the phases of the procedural step - performance of audits of the work of STIVs - which is: administrative and legal aspects of work, facility, instruments, equipment, work of the vehicle roadworthiness supervisor, work of the agents for technical inspection and registration of vehicles, as well as legal management of financial means. As can be seen from Figure 6 in all aspects of the work (except in legal management of financial means) of STIVs in 2007 a significant increase of irregularities was determined.

It is alarming that precisely the aspect of work of STIVs which has the highest and most direct influence on the traffic safety - work of the vehicle roadworthiness supervisor - marks the highest increase in the determined irregularities, meaning 200 determined irregularities in 2007 compared to 13 determined irregularities in 2006, which is an increase of more than 15 times.

However, each detected irregularity in the work of STIVs was processed by the authorized auditors of the Croatian Automobile Club defining its cause and method of its elimination.

\section{CONCLUSION}

The benefits of introducing the quality management system according to the requirements of the Standard in the internal aspect of activities mean pre-

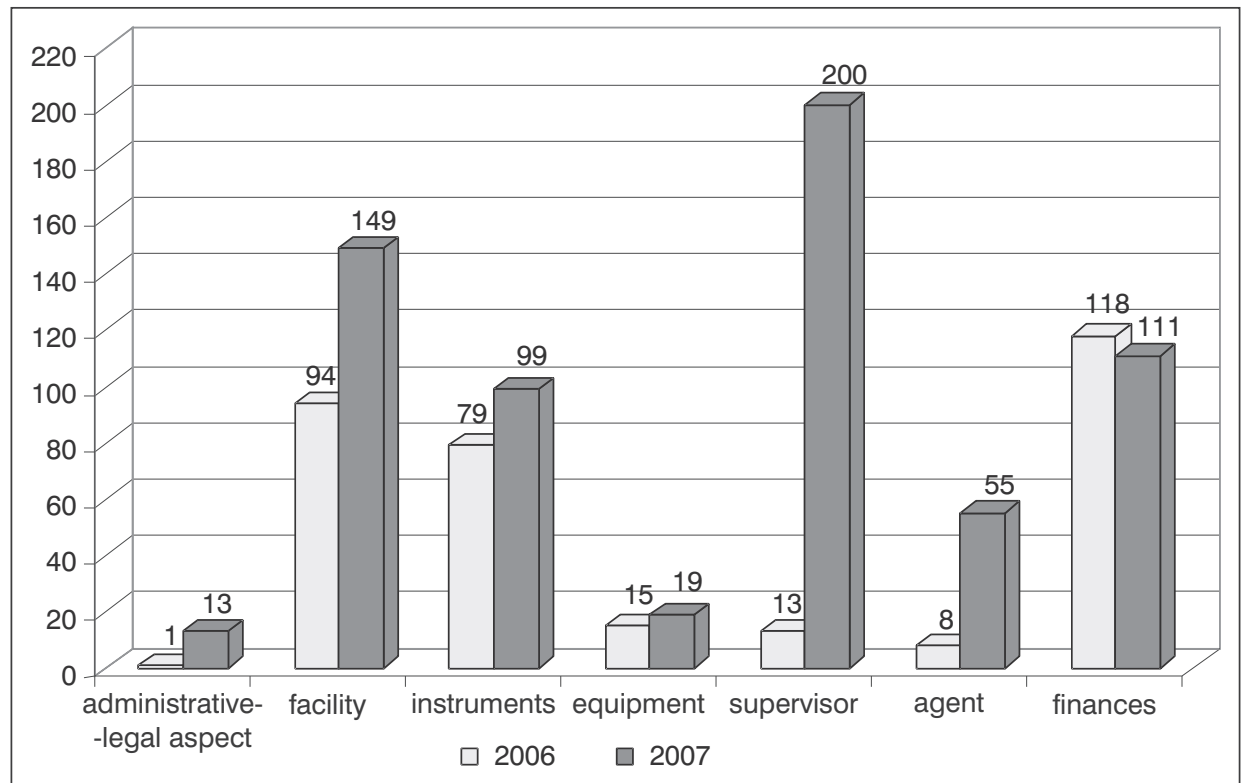

Figure 6 - Structure of the determined irregularities in the work of the STIVs in 2006 and 2007

Source: Electronic database of performed audits (Report), Croatian Automobile Club, Zagreb. 
cise definition of the processes, establishment of control points in all the procedural steps with defined responsibilities (organizers of activities), establishment of the process analyses mechanisms and continuous improvement. The synergic effect of the mentioned benefits represents significantly improved quality and efficiency in performing the audits over the work of the STIVs.

Quality improvement of implementing the respective activities is primarily reflected in the context of detecting and correcting the irregularities in the work of the STIVs. Consequently, the STIVs improve their work especially in the context of determining the technical irregularities on vehicles, which implies their elimination i. e. realizing the vehicle roadworthiness. The exclusion of technically defective vehicles from road traffic affects directly the raising of the road traffic safety level.

The first year in which the Croatian Automobile Club introduced the new operation methodology in performing the audits over the work at STIVs, in compliance with the requirements of the Standard, was 2007. This year may be considered the reference year regarding the assessment of the System condition, and based on the collected and processed data it will be possible to make comparisons and assessments for the future years.

\section{Dr. sc. GORAN ZOVAK}

E-mail: zovak@fpz.hr

Sveučilište u Zagrebu, Fakultet prometnih znanosti

Vukelićeva 4, 10000 Zagreb, Republika Hrvatska

Dr. sc. IVO ČALA

E-mail: icala@fsb.hr

Sveučilište u Zagrebu, Fakultet strojarstva i brodogradnje Ivana Lučića 1, 10000 Zagreb, Republika Hrvatska

IGOR ŠIŠKO, dipl. ing. stroj.

E-mail: igor.sisko@hak.hr

Hrvatski Autoklub

Avenija Dubrovnik 44, 10010 Zagreb, Republika Hrvatska

\section{SAŽETAK}

\section{PRIMJENA NORMI U STRUČNOM NADZORU NAD RADOM STANICA ZA TEHNIČKI PREGLED VOZILA}

Zahtjevi HRN EN ISO/IEC 17020:2005 primijenjeni su na djelatnost stručnog nadziranja rada stanica za tehnički pregled vozila koju, u sklopu sustava tehničkih pregleda i registracije vozila Republike Hrvatske, obavlja Hrvatski Autoklub, temeljem javne ovlasti Ministarstva unutarnjih poslova Republike Hrvatske. Primjena navedene norme, odnosno implementiranje sustava upravljanja kvalitetom, za direktnu posljedicu ima povećanje kvalitete i efikasnosti u obavljanju predmetne djelatnosti, čime se postiže podizanje razine tehničke ispravnosti vozila, odnosno sigurnosti prometa na cestama u Republici Hrvatskoj.

\section{KLJUČNE RIJEČI}

nadzorna/inspekcijska tijela, kvaliteta, upravljanje kvalitetom, tehnički pregled vozila, stručni nadzor

\section{LITERATURE}

[1] Zakon o sigurnosti prometa na cestama (Road Traffic Safety Act), NN (Official Gazette) 105/04.

[2] Pravilnik o stručnom nadzoru nad radom stanica za tehnički pregled vozila (Regulations on auditing of the work of stations for technical inspection of vehicles), Off. Gazette 159/04, 6/05, 32/07.

[3] HRN EN ISO/IEC 17020, Hrvatski zavod za norme (Croatian Institute for Standards, Zagreb, 2005

[4] N. Injac: Mala enciklopedija kvalitete, Upoznajmo normu (Small encyclopaedia of quality, Let us meet the standard) ISO 9000, Oskar, Zagreb, 2002.

[5] Joseph M. Juran: Management of Quality Control, New York, New York, 1967.

[6] Croatian Automobile Club Bulletin, Stručni nadzor nad radom stanica za tehnički pregled vozila (Auditing the work of stations for technical inspection of vehicles), Croatian Automobile Club, Zagreb, 2007

[7] Dokumentacija sustava upravljanja kvalitetom (Quality Management System Documentation), Croatian Automobile Club, Zagreb, 2008

[8] ISO Quality Management Principles, http://www.iso.org/iso/home.htm

[9] EA IAF/ILAC Guidance on the application of ISO/IEC 17020:1998, EA IAF/ILAC -A4, European co-operation for Accreditation, 2004 